Article

\title{
Advancing Households' Sustainable Energy through Gender Attitudes towards Rooftop PV Installations: A Case of the Central Highlands, Vietnam
}

\author{
Sopin Jirakiattikul ${ }^{1}$, Tran Thi Lan ${ }^{2,3}$ (D) and Kuaanan Techato $2,4,5, *$ (D) \\ 1 Faculty of Economics, Prince of Songkla University, Songkhla 90112, Thailand; sopin.j@psu.ac.th \\ 2 Faculty of Environmental Management, Prince of Songkla University, Songkhla 90112, Thailand; \\ tranthilan@ttn.edu.vn \\ 3 Faculty of Economics, Tay Nguyen University, Đắk Lắk 30000, Vietnam \\ 4 Environmental Assessment and Technology for Hazardous Waste Management Research Center, Faculty of \\ Environmental Management, Prince of Songkla University, Songkhla 90112, Thailand \\ 5 Program Sustainable Energy Management, Faculty of Environmental Management, Prince of Songkla \\ University, Songkhla 90112, Thailand \\ * Correspondence: kuaanan.t@psu.ac.th; Tel.: +66-74-426-843
}

Citation: Jirakiattikul, S.; Lan, T.T.; Techato, K. Advancing Households' Sustainable Energy through Gender Attitudes towards Rooftop PV Installations: A Case of the Central Highlands, Vietnam. Sustainability 2021, 13, 942. https://doi.org/ $10.3390 /$ su13020942

Received: 23 December 2020

Accepted: 14 January 2021

Published: 18 January 2021

Publisher's Note: MDPI stays neutral with regard to jurisdictional claims in published maps and institutional affiliations.

Copyright: (c) 2021 by the authors. Licensee MDPI, Basel, Switzerland. This article is an open access article distributed under the terms and conditions of the Creative Commons Attribution (CC BY) license (https:// creativecommons.org/licenses/by/ $4.0 /)$.
Abstract: The report shows that there was no disparity between males and females in their attitude to rooftop solar electricity systems (rooftop PV) installations. Government motivation is the key factor that affects householders' attitudes to rooftop PV. Three other factors-households' perception, education and environment mentioning-were also crucial for the research model. Meanwhile, six factors had no significant effect on the dependent variables—-these consisted of age, gender, rooftop material, level of electricity consumption, income per family member and household innovativeness.

Keywords: gender attitude; central highlands; rooftop PV; sustainable energy; Vietnam

\section{Introduction}

Solar power is an unlimited alternative sustainable power source. In recent years, the levelized cost of electricity for solar energy has decreased sharply and it can compete with other energy sources [1-5]. Moreover, solar energy is suitable for all regions, especially the southern areas and the Central Highlands of Vietnam [6].

However, most of the electricity supplied throughout Vietnam comes from large hydropower dams, coal and gas [7]. The disadvantages of large dams have been shown as loss of productive land, and inundation [8,9]. Moreover, hydropower depends on water discharge, and the electricity demand excess during the hot season has led to security problems for the power sector in Vietnam [10,11]. In addition, electricity from coal in Vietnam is also harmful to the environment [12] because Vietnam's coal-fired power plants use anthracite coal to produce energy, resulting in ash content of up to $33 \%$ by weight. In Vietnam, therefore, coal-fired electricity generation has major emission issues [13].

The Government of Vietnam, as well as those of other countries, encourages the development of sustainable energy to protect the environment and ensure national energy security, for which there are regulations consulting and guiding solar energy development. In particular, the rooftop solar electricity system (rooftop PV) has many strong points, such as taking advantage of the gaps in roofs, not occupying productive land as a solar farm does, providing a large portion of electricity for on-site enjoyment, reducing pressure on the grid, and not having to replace the battery every 2 to 5 years [14]. People who install this system can sell excess electricity to Vietnam Electricity (EVN) and can use free electricity only four years after installation, depending on their level of electricity consumption [15]. Because of these benefits, the Vietnamese government encourages solar 
energy development with the highest feed-in tariff (FIT) prices of all solar energy types, as well as the other types of energy [16].

There were 26,876,079 households in Vietnam in 2019 [17]. However, until 30 April 2020 , only 27,631 rooftop PVs were installed, meaning they occupied $1.28 \%$ of the total number of households in all areas. The Central Highlands region is no exception, and it is a potential and suitable market for rooftop PV installations [18].

Attitude is a fundamental factor that has a great influence on customer behaviour. It plays an important role in promoting the development of a product [19]. According to Wilkie and Pessemier (1973), the word "attitude" originated from the Latin term of mental or bodily belief. In general, attitudes of people relate to their actions or activity categories [20]. Allport (1935) suggested that the attitudes of a person are the neural readiness status and are embodied through their experience. This dynamically and directly impacts people's responses toward situations and objects. To put it simply, the attitudes of consumers toward a product is defined as the willingness of customers to accept and buy the product [21]. Hawkins et al. (2007) believed that attitude is a situation of motivation, emotion, perception, and cognition, which connects to several views on the environment. Thus, attitudes are affected by stimulation from the environment; for example, how the seller communicates to supply products to the buyers [22].

According to Solomon (2002), an attitude object is anything that people make a decision about or have a good or bad feeling about. In terms of consumer-oriented attitude definition, the term objects are defined largely as consisting of special concepts of marketing relationships or consumption; for instance, price, advertisement, quality of product, product use, physical proof, retailer and service staff [23].

There has been some research about customer attitudes to rooftop PV [24-26]. However, there has been no study on the attitudes of households in Vietnam in general, nor in the Central Highlands in particular. In addition to the great potential for solar energy, there are also differences in Vietnam's policies to promote solar energy and characteristics such as the perceptions held by the population about the PV rooftop system, knowledge of environmental protection, as well as the electricity price level applied to households. Therefore, researching attitudes to rooftop PV held by households in Vietnam will be an interesting study for many stakeholders, such as supplier partners and policymakers concerned with sustainable energy development. The research report aims to identify the key factors that influence householders' gender attitudes in order to encourage them to install rooftop PV for their houses. This would enhance sustainable energy development and contribute to minimizing the negative impact of conventional energy in the research area. From the study results, the authors will propose recommendations to help the Vietnamese government introduce more effective policies to enhance the proportion of sustainable energy used in the total power supply of the country.

There are three main kinds of solar PV, in which the smart grid has a lot of advantages compared to off-grid and hybrid solar systems; for example, the smart-grid is the cheapest system (as much as half of the other system's cost). The people who install that system do not need to replace battery every $2-5$ years. In addition, it is available to sell surplus electricity to the Vietnam Electricity Corporation (EVN), and of course, it can be installed in the Central Highlands where has a high potential solar energy and available national grid. Therefore, the research was concentrated on the household's attitude for the smart grid (SG) rooftop PV system. The cost of this system was calculated based on six levels of electricity consumption, illustrated in previous research. The quoted cost of an SG rooftop PV installation in Vietnam ranged between USD 850 and over 1200 per $\mathrm{kWp}$ and the cost of USD 1200 per $\mathrm{kWp}$ was adopted in order that households can choose high-quality equipment. The payment for that system ranges from USD 360 to USD 3960 due to the households' level of electricity consumption [15]. The initial cost for SG rooftop solar is quite high. Recently, support from the Vietnamese Government is only by fit in tariff (FIT).

Although the educational gap has narrowed, differences in earnings between genders in Vietnam still occur. The earnings of females have often been lower than that of men 
due to the work that they undertake [27]. Investing in a rooftop PV system requires a very expensive investment, related to the financial capacity of the installer. In this study, we would like to examine the gender gap in attitudes towards PV rooftop installations to determine if there is a gender gap in the attitude of a costly investment related to sustainable energy. Through this study, policy makers will decide whether men or women could approach renewable energy development policy more effectively.

\section{Materials and Methods}

\subsection{Data Collection}

The data were collected in Daklak Province, located in the middle of the Central Highlands, with the highest population compared to the other four provinces in the area. This province is considered the metropolis of the region [28,29]. The data collection started with a pre-survey. The questionnaires were in local language, Vietnamese. In total, 10 questionnaires were sent to 10 households in the pre-survey to test if the questionnaires were being comprehended in the real survey. After pre-survey, we adjusted the questionnaire for the real survey. A sample of 300 households in the research area was chosen for the main survey. The data were collected from May to July 2019 with convenience random sampling. The survey was conducted only with married householders who had appropriate rooftops for the system installation, because unmarried people in Vietnam often live with their parents and they cannot make their own decisions. The households who took part in the research had not installed rooftop PV, a factor which tests their attitude to a new energy resource for their houses.

\subsection{Research Model and Analysis}

Some important customer attitude models were explored to determine the association of customer attitude and behaviour, such as the model of trilogy attitudes, the multiattribute attitude model, the trying-to-consumer model, and attitude-toward-the-ad model. Each model offered various aspects of how the details were organized or linked.

\subsubsection{The Trilogy of Attitude Model}

Howard and Sheth (1969), cited in Daubry (2012), suggested that customers' attitudes consist of three main attributes: cognitive, conative and affect. The three attributes are examined simultaneously since they are highly collective, and together reflect the emotions of customers toward products [21].

\section{Cognitive Component}

According to Ostrom (1969), the cognitive component is mentioned as the acknowledgment, notion, and opinions that people have about the object or concept. People's cognition is related to perceptions and knowledge, which integrate related information from different resources and attitude objects. The resulting perceptions and knowledge are generally understood as beliefs. Consumers believe that the attitude object acquires different features, and that special behaviour can lead to special outcomes. The cognitive factor of consumer attitude is also known as a belief [30].

\section{Affective Component}

The affective factors of attitudes indicate negative or positive feelings, emotions or judgments that relate to the attitude object. Affective factors reflect the consumer's feeling toward an attitude object. They refer to the emotional content and stimulations that people like or dislike about a specific object. According to Chisnall (1975), feelings can be acquired from individual characteristics, purposes or social standards. The affective component of an attitude will be created from consumers' emotions or feelings about a particular product [31]. According to Johnson and Zinkhan (1991), good or bad experiences can be enhanced or amplified through customers' emotional states, and then they may impact the ways that people act [32]. 


\section{Conative Component}

The conative component illustrates people's behaviour toward an attitude object. Kalwani and Silk (1982) argued that the choices of customers who regularly buy products can be forecasted from behavioural intention scales [33]. According to Anthony et al. (1989), the reactions of a conative component are behavioural tendencies, purposes, activities, and responsibilities with a connection to the attitude object. Beginning with verbal interpretation, a researcher could examine what individuals intend to do, what they say, what they do, or what they would do if they are in a suitable situation [34]. According to McLeod (2009), behaviour is the aspect of attitude that has an impact on how people act or behave [35]. Studying consumer behaviour is an investigation into how organizations, groups or individuals buy, use, select and adopt goods, ideas, services, or acquirements to fulfil their wants and needs. The sellers have to thoroughly understand the theories and realities of buyer behaviour [36].

The relatively stable and balanced relationship will be maintained among these three components of attitude. If one attitude component changes, the other component of attitude will also change [22]. All three components create the overall attitude of a person to an object or idea.

\subsubsection{Multi-Attribute Attitude Model}

The multi-attribute model is applied to interpreting and measuring attitudes. The fundamental model has three components, which are important weights, beliefs and attributes. Attributes are the typical features of an attitude object. Beliefs are used to measure a specific attribute. Important weights are used to indicate the priority or importance of a specific attribute. The multi-attribute model may be applied to estimate the overall attitude of consumers.

The most important multi-attribute model is the Fishbein model. This model also uses three elements of attitude. The first component is remarkable beliefs, which may be in relation to those convictions an individual might have throughout the assessment of a service or product. The second component is object-attribute linkage, which is an indicator of the likelihood for a specific quality to be connected with an attitude object. The third factor is an estimation for claiming the importance of the attribute [37].

\subsubsection{Trying to Consume Model}

The trying to consume model concentrates on a real situation of purchase, but the action of behaviour is not definite and may sometimes even be in the future. In terms of this model, the action of behaviour is directed towards things that the buyer will do or attempt to do in the future. In such processes of trying, the results cannot be forecasted for certainty. This model indicates the consumer's aims at consumption, which is hindered by individual and environmental obstacles, thus preventing the purchase action from happening. Personal obstacles happen when a person faces an approach to eliminate conflict [38].

\subsubsection{Attitude-Toward-The-Ad Model}

The attitude-toward-the-ad model suggests that consumers create different feelings (affects) and perceptions (cognitions) when an advertisement is displayed, which influences the attitudes of consumers towards the brand and the advertisement. The cognitive component makes customers believe the brand and determines their attitude to the ad. The affects element also impels customers to be convinced by the brand and determines their attitude towards the ad. Therefore, both these components impact the attitudes of consumers toward the ad and their credence of the brand. A simple display of the ad may also make customers believe in the trademark. Consequently, the trust in the brand and the attitude towards the ad help to develop an attitude towards the brand [38].

Developing country literature on adoption of new methods and technology for renewable energy. 
According to Esmailzadeh et al. (2020), knowledge technology is a critical component of the innovation process. Nevertheless, developing economies lag off in this role. On the other hand, developed nations generally work at the forefront of innovation as well as awareness, assisting them to become more innovative [39].

Rogers suggested that the spread of a new idea is influenced by four key elements, namely, innovation itself, channels of communication, time, and a system of governance. The method depends on human investment innovation and should be widely applied in order to be self-sustaining. There is a point at which innovation reaches a critical mass within the rate of adoption. Innovators, early adopters, early majority, late majority, and laggards are the adopter groups. Diffusion expresses itself in numerous forms and is strongly subject to the form of adopters and the mechanism of innovation-decision. Innovation, defined as the degree to which an individual adopts a new concept, is the criterion for the categorization of adopters [40].

\subsubsection{The Role of Government in the Development of Sustainable Energy}

Governments play an important role in renewable energy development. Market development for PV systems depends heavily on government regulations. The key obstacle to the implementation of rooftop PV is high costs, and a clear relationship of investment compensation to minimize capital costs is necessary [24]. Recently, the Vietnamese government supported FIT for all people who install rooftop PV systems [16].

Based on those theories, the research model was proposed as follows:

Household - attitude $=f$ (Social demographics, Householders' perception, Environmental mention, Householders' innovativeness, Government's motivation)

Dependent and independent variables were determined using subjects used in earlier studies, which were adjusted to align with the Vietnamese context.

On the basis of the theoretical and empirical literature cited above, the following hypotheses applying to attitudes towards rooftop PV installation were proposed in Figure 1:

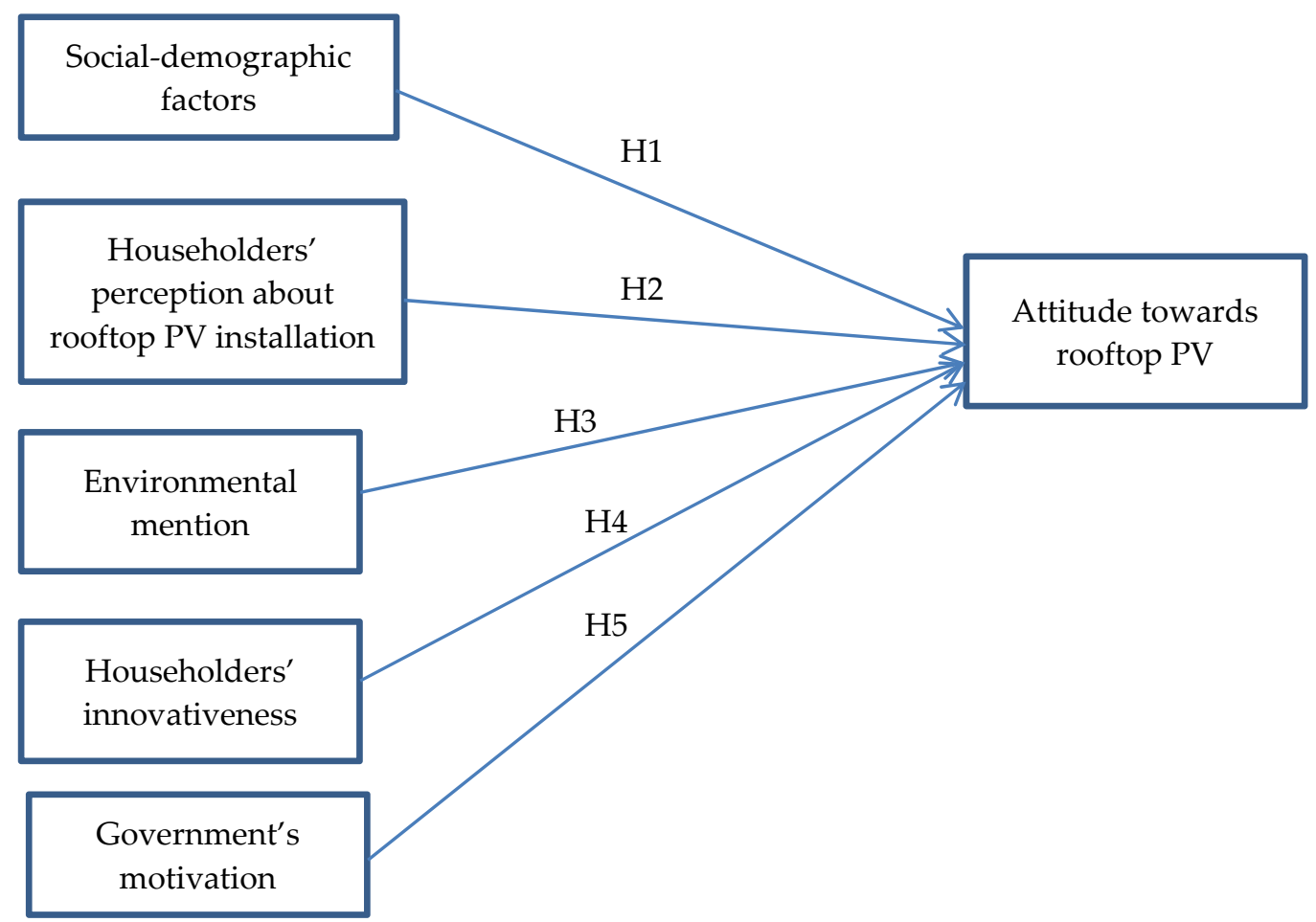

Figure 1. Research model. 
Hypothesis 1 (H1). There is a disparity between males and females, and there are significant relationships between social-demographic factors and attitude towards rooftop PV installations.

Hypothesis 2 (H2). There is a significant relationship between householders' perceptions and attitudes towards rooftop PV installations.

Hypothesis 3 (H3). There is a significant connection between environmental concern and attitudes towards rooftop PV installations.

Hypothesis 4 (H4). There is a significant relationship between householders' innovativeness and attitudes towards rooftop PV installations.

Hypothesis $\mathbf{5}$ (H5). There is a significant relationship between government motivation and attitudes towards rooftop $P V$ installations.

An independent samples T-test [41] was used to determine the difference between male and female attitudes to rooftop PV installations. In this test, if the $p$-value (Sig. 2-tail) $<0.05$, we conclude that there is a difference.

Multi regression and factor analysis was used for measuring the relationship between the rest of the independent variables and the dependent variable (Householders' attitude). The dependent attitude variable and the independent variables (Householders'_perception, Environmental_mention, Household_innovativeness, Government_motivation) in H2, H3, H4, H5, were answered on a 5-point Likert scale, with 1 for strongly disagree and 5 for strongly agree. Therefore, reliability analysis and Exploratory Factor Analysis (EFA) are necessary in this situation to allow for the exclusion of inappropriate variables in the study model. In addition, multi-collinearity diagnostics were determined to test the relationship among the independent variables that make the model incorrect.

\section{Reliability Analysis}

A reliability analysis was used in the qualitative research, where the data were determined using the Cronbach's alpha to test coherence, which indicates the close relationship of the objects to the group. Correct item-total correlation reflects the contribution of the variables. Reliability was deemed appropriate when Cronbach's alpha coefficient $\geq 0.7$ and correct item-total correlation was greater than 0.3 [42].

\section{Exploratory Factor Analysis}

The Exploratory Factor Analysis (EFA) was used to classify factors that have an effect on householders' attitudes towards rooftop PV installations. The conditions of the analysis were as follows:

Bartlett test (Sig. $<0.05$ ) and the average variance extracted $>50 \%$;

Factor loading $>0.5$ and Kaiser-Meyer-Olkin (KMO) $0.5 \leq \mathrm{KMO} \leq 1$; The variables with $\mathrm{KMO}<0.5$ were removed from the model [42].

\section{Multicollinearity Diagnostics}

Multicollinearity is a feature of independent variables that are closely associated with each other. The regression model with a multicollinearity phenomenon would not make the findings of a quantitative study relevant and correct. Variance Inflation Factors (VIF) were used to calculate collinearity, and tolerance values were used to assess the multicollinearity phenomenon. Menard (1995) claimed that a tolerance of less than 0.20 is a major concern. Appropriately, a tolerance of just under 0.10 is likely to trigger a significant collinearity problem. Since VIF are the opposite of tolerance, the tolerance of 0.20 applies to rule 5 and the tolerance of 0.10 to rule 10 . [43]. 
Hair et al. (1995), indicated that a VIF of less than 10 is indicative of irrelevant collinearity [44]. Kennedy (1992) argued that VIF >10 implies a detrimental collinearity for standardized finding collinearity for standardized findings [45].

\section{Results}

\subsection{Demographics of Respondents}

The demographics of the respondents also represented the demographic variables. The study was conducted with a sample of 300 households in the Central Highlands, of which $51 \%$ were male. In total, $100 \%$ were married. The majority of them had their education of high school and college with the percentages $53.3 \%$, and $34 \%$, respectively. Postgraduate responses comprised $12 \%$. None of them had primary school education. In terms of rooftop material, $48 \%$ were corrugated iron roof, the rest were tile roof, concrete flat roof and others (department accommodation, asbestos-cement shingle) with $22.3 \%$, $12 \%$ and $17.7 \%$ correspondingly. Electricity retail price in Vietnam has been divided into six levels, with the higher price level for the higher levels. Most people consumed electricity at levels 3 and 4, with a percentage of $39.7 \%$ and $29 \%$, respectively. As regards income per family member in the previous year, $42.3 \%$ income of the respondents ranged from USD 1000-2999; following that were incomes of USD 3000-4999 and USD 4000-6999. The detailed information of the respondents is illustrated in Table 1.

Table 1. Profile of respondents.

\begin{tabular}{|c|c|c|c|c|}
\hline Demographic Variables & Explanations & Category & Frequency & Percentage \\
\hline & & Total (households) & 300 & 100 \\
\hline \multirow{5}{*}{ Age } & \multirow{5}{*}{$\begin{array}{c}\text { Age } \\
\text { (in year) }\end{array}$} & $20-30$ & 7 & 2.3 \\
\hline & & $31-40$ & 109 & 36.3 \\
\hline & & $41-50$ & 125 & 41.7 \\
\hline & & $51-60$ & 55 & 18.3 \\
\hline & & Over 60 & 4 & 1.3 \\
\hline \multirow{2}{*}{ Gender } & \multirow{2}{*}{ Gender } & Male & 153 & 51.0 \\
\hline & & Female & 147 & 49.0 \\
\hline \multirow{5}{*}{ Education } & \multirow{5}{*}{ Education } & Primary school & 0 & 0 \\
\hline & & Secondary school & 2 & 0.7 \\
\hline & & High school & 160 & 53.3 \\
\hline & & College & 102 & 34.0 \\
\hline & & Postgraduate & 36 & 12.0 \\
\hline \multirow{4}{*}{ Rooftop-material } & \multirow{4}{*}{ Rooftop material } & Corrugated iron roof & 144 & 48 \\
\hline & & Tile roof & 67 & 22.3 \\
\hline & & Concrete flat roof & 36 & 12 \\
\hline & & Others & 53 & 17.7 \\
\hline \multirow{6}{*}{ Level_electricity_consumed } & \multirow{6}{*}{$\begin{array}{l}\text { Level of power } \\
\text { consumption } \\
\quad(\mathrm{kWh})\end{array}$} & Level 1: 0-50 & 0 & 0 \\
\hline & & Level 2: 51-100 & 49 & 16.3 \\
\hline & & Level 3: 101-200 & 119 & 39.7 \\
\hline & & Level 4: 201-300 & 87 & 29.0 \\
\hline & & Level 5: 301-400 & 31 & 10.3 \\
\hline & & Level 6: 400 & 14 & 4.7 \\
\hline
\end{tabular}


Table 1. Cont.

\begin{tabular}{|c|c|c|c|c|}
\hline Demographic Variables & Explanations & Category & Frequency & Percentage \\
\hline \multirow{9}{*}{ Income_per_family_member } & \multirow{9}{*}{$\begin{array}{l}\text { Income per family } \\
\text { member in the } \\
\text { previous year }\end{array}$} & $<1000$ & 0 & 0 \\
\hline & & 1000-2999 & 127 & 42.3 \\
\hline & & $3000-4999$ & 62 & 20.7 \\
\hline & & $5000-6999$ & 54 & 18.0 \\
\hline & & 7000-8999 & 25 & 8.3 \\
\hline & & $9000-10,999$ & 7 & 2.3 \\
\hline & & $11,000-12,999$ & 9 & 3.0 \\
\hline & & $13,000-14,999$ & 12 & 4.0 \\
\hline & & $\geq 15,000$ & 4 & 1.3 \\
\hline
\end{tabular}

Source: Household survey in the research area.

\subsection{Test the Difference of Genders' Attitude towards Rooftop PV}

Independent sample $T$-test was used to test the difference of genders' attitude towards rooftop PV. The results in Table 2 show that the sig value (2-tailed) or sig values were greater than 0.05; thus, there were no significant disparities between men and women in their attitudes toward rooftop PV installation.

Table 2. Independent samples test tests the difference of genders' attitude towards rooftop PV.

\begin{tabular}{|c|c|c|c|c|c|c|c|c|c|c|}
\hline & & \multicolumn{2}{|c|}{$\begin{array}{c}\text { Levene's Test for } \\
\text { Equality of Variances }\end{array}$} & \multicolumn{7}{|c|}{$T$-Test for Equality of Means } \\
\hline & & \multirow[t]{2}{*}{ F } & \multirow[t]{2}{*}{ Sig. } & \multirow[t]{2}{*}{$\mathbf{T}$} & \multirow[t]{2}{*}{ Df } & \multirow[t]{2}{*}{$\begin{array}{c}\text { Sig. } \\
\text { (2-Tailed) }\end{array}$} & \multirow[t]{2}{*}{$\begin{array}{c}\text { Mean } \\
\text { Difference }\end{array}$} & \multirow[t]{2}{*}{$\begin{array}{l}\text { Std. Error } \\
\text { Difference }\end{array}$} & \multicolumn{2}{|c|}{$\begin{array}{l}95 \% \text { Confidence } \\
\text { Interval of the } \\
\text { Difference }\end{array}$} \\
\hline & & & & & & & & & Lower & Upper \\
\hline \multirow{2}{*}{ 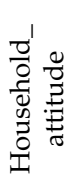 } & $\begin{array}{l}\text { Equal variances } \\
\text { assumed }\end{array}$ & \multirow{2}{*}{0.019} & \multirow{2}{*}{0.892} & 0.095 & 298 & 0.924 & 0.0079587 & 0.0836858 & -0.1567313 & 0.1726488 \\
\hline & $\begin{array}{l}\text { Equal variances } \\
\text { not assumed }\end{array}$ & & & 0.095 & 297.596 & 0.924 & 0.0079587 & 0.0836803 & -0.1567214 & 0.1726389 \\
\hline
\end{tabular}

Source: Calculation from the data of households' survey in the research area.

\subsection{Reliability and Factor Statistics}

As mentioned in the methods section, before implementing the regression model to determine household attitudes toward rooftop PV, reliability was conducted with the variables that related to the questions in the 5-point Likert scale in $\mathrm{H} 2, \mathrm{H} 3, \mathrm{H} 4$, and H5. Exploratory factor analysis was tested for all variables to ensure the variables were appropriate for the model. The reliability and EFA were tested separately, with dependent and independent variables, as illustrated in Tables 3 and 4.

As shown in Table 3, the dependent variable is suitable for the model since Cronbach's alpha, factor loading and KMO satisfied the theoretical conditions.

In terms of the independent variables in Table 3, the Cronbach's alpha of household perception was 0.634 . Hence, the Cronbach's alpha coefficient $\geq 0.7$ is suitable for the model. Therefore, five items in the Householders' perception variable from the first-time measure had to be rechecked. (See Table 4). 
Table 3. Reliability and EFA of dependent variable.

\begin{tabular}{|c|c|c|c|c|}
\hline Variables & Explanation & Factor Loading & Number of Items & Cronbach's Alpha \\
\hline Households' attitudes & $\begin{array}{l}\text { Households' opinion toward } \\
\text { installing a rooftop PV system }\end{array}$ & & \multirow{4}{*}{3} & \multirow{4}{*}{0.882} \\
\hline Attitude1 & $\begin{array}{l}\text { 1. I think that rooftop PV is a good } \\
\text { and reliable long-term investment }\end{array}$ & 0.920 & & \\
\hline Attitude2 & $\begin{array}{l}\text { 2. I think that a rooftop PV system } \\
\text { will increase the utility of my house }\end{array}$ & 0.895 & & \\
\hline Attitude3 & $\begin{array}{l}\text { 3. I think that rooftop PV is good for } \\
\text { the environment because it can } \\
\text { mitigate global warming }\end{array}$ & 0.886 & & \\
\hline
\end{tabular}

Note: $\mathrm{KMO}=0.736$, Bartlett test $($ Sig. $=0.000$ ) and the average variance extracted $=81.809 \%$.

Table 4. Reliability and EFA of independent variables.

\begin{tabular}{|c|c|c|c|c|}
\hline Variables & Explanation & Factor Loading & Number of Items & Cronbach's Alpha \\
\hline \multicolumn{5}{|l|}{ Social demographic factor } \\
\hline Household_perception & $\begin{array}{c}\text { Households' perception about } \\
\text { rooftop PV }\end{array}$ & & \multirow{6}{*}{5} & \multirow{6}{*}{0.634} \\
\hline Perception 1 & $\begin{array}{l}\text { 1. The rooftop PV system will supply } \\
\text { power to my household throughout } \\
\text { the day. }\end{array}$ & 0.818 & & \\
\hline Perception 2 & $\begin{array}{l}\text { 2. Installing rooftop PV will help my } \\
\text { households to reduce the monthly } \\
\text { power bill }\end{array}$ & 0.894 & & \\
\hline Perception 3 & $\begin{array}{l}\text { 3. Rooftop PV will be a source of } \\
\text { alternative energy in the future. }\end{array}$ & 0.660 & & \\
\hline Perception 4 & $\begin{array}{l}\text { 4. Power can be generated in the } \\
\text { winter by rooftop PV. }\end{array}$ & 0.865 & & \\
\hline Perception 5 & $\begin{array}{l}\text { 5. The roof of my house will be } \\
\text { protected from external factors and } \\
\text { increase its lifespan by installing } \\
\text { rooftop PV. }\end{array}$ & 0.869 & & \\
\hline Environmental_mention & $\begin{array}{l}\text { The household's mention of the } \\
\text { environmental conservation features } \\
\text { of rooftop PV. }\end{array}$ & & \multirow{4}{*}{3} & \multirow{4}{*}{0.871} \\
\hline Environmental_mention 1 & $\begin{array}{l}\text { 1. Rooftop PV will help mitigate } \\
\text { climate change }\end{array}$ & 0.850 & & \\
\hline Environmental_mention 2 & $\begin{array}{l}\text { 2. I will contribute to the } \\
\text { sustainability of nature and } \\
\text { humanity if I install a rooftop PV } \\
\text { system. }\end{array}$ & 0.886 & & \\
\hline Environmental_mention 3 & $\begin{array}{l}\text { 3. The owner of a rooftop PV will } \\
\text { feel better since the system does not } \\
\text { affect the climate. }\end{array}$ & 0.878 & & \\
\hline Household_innovativeness & $\begin{array}{l}\text { Innovativeness of the household in } \\
\text { relation to new energy options }\end{array}$ & & \multirow{4}{*}{3} & \multirow{4}{*}{0.849} \\
\hline Innovativeness 1 & $\begin{array}{l}\text { 1. I will be interested in trying to } \\
\text { install rooftop PV if I know that it is } \\
\text { available }\end{array}$ & 0.866 & & \\
\hline Innovativeness 2 & $\begin{array}{l}\text { 2. I've found more knowledge about } \\
\text { rooftop PV than my friends }\end{array}$ & 0.886 & & \\
\hline Innovativeness 3 & $\begin{array}{l}\text { 3. Even though none of my friends } \\
\text { have tried to install rooftop PV, I will } \\
\text { do it }\end{array}$ & 0.844 & & \\
\hline
\end{tabular}


Table 4. Cont.

\begin{tabular}{|c|c|c|c|c|}
\hline Variables & Explanation & Factor Loading & Number of Items & Cronbach's Alpha \\
\hline Government_motivation & $\begin{array}{l}\text { Government incentives relating to } \\
\text { smart-grid rooftop solar electricity }\end{array}$ & & \multirow{5}{*}{4} & \multirow{5}{*}{0.817} \\
\hline Government_motivation 1 & $\begin{array}{l}\text { 1. I think the Vietnamese } \\
\text { government's policies are good for } \\
\text { promoting rooftop PV }\end{array}$ & 0.794 & & \\
\hline Government_motivation 2 & $\begin{array}{l}\text { 2. The government is now } \\
\text { offering a 20-year feed-in tariff to } \\
\text { buy back power } \\
\text { from rooftop PV at } 9.35 \mathrm{US} \\
\text { cent } / \mathrm{kWh} \text {, which is appealing to me }\end{array}$ & 0.796 & & \\
\hline Government_motivation 3 & $\begin{array}{l}\text { 3. I think that the government } \\
\text { incentive for rooftop PV will } \\
\text { motivate people to install that } \\
\text { system for their house }\end{array}$ & 0.800 & & \\
\hline Government_motivation 4 & $\begin{array}{l}\text { 4. I assume that the government } \\
\text { incentive for rooftop PV will } \\
\text { continue for a long time }\end{array}$ & 0.801 & & \\
\hline
\end{tabular}

Note: $\mathrm{KMO}=0.754$, Bartlett test $(\mathrm{Sig} .=0.000)$ and the average variance extracted $=73.173 \%$.

When rechecking the variable, it was found that Perception 1 and Perception 2 did not meet the requirement. The values of correct item-total correlation for these two variables were 0.127 and 0.197 , respectively, which were less than the theory requirement 0.3 ; thus, these two items had to be removed. After removing the items, the Cronbach's alpha of the household perception variable was 0.884 , and suitable for the model. The rotated component matrix in Table 5 illustrates how many factors existed among the independent variables.

Table 5. Rotated Component Matrix ${ }^{\mathrm{a}}$.

\begin{tabular}{ccccc}
\hline & \multicolumn{4}{c}{ Component } \\
\cline { 2 - 4 } & $\mathbf{1}$ & $\mathbf{2}$ & $\mathbf{3}$ & $\mathbf{4}$ \\
\hline Government_motivation4 & 0.802 & & \\
Government_motivation3 & 0.799 & & \\
Government_motivation2 & 0.795 & & \\
Government_motivation1 & 0.794 & & & \\
Perception2 & & 0.902 & & \\
Perception4 & & 0.880 & & \\
Perception5 & & & & \\
Environmental_mention2 & & & 0.890 & \\
Environmental_mention3 & & & & 0.848 \\
Environmental_mention1 & & & & 0.884 \\
Innovativeness2 & & & & \\
Innovativeness1 & & & & \\
Innovativeness3 & & & & \\
\end{tabular}

Extraction Method: Principal Component Analysis. Rotation method: Varimax with Kaiser Normalization.

${ }^{\text {a }}$ Rotation converged in 5 iterations.

The Rotated Component Matrix shows that H2, H3, H4 and H5 consist of four factors equivalent to four groups of independent variables.

Based on the analysis, the independent variable can be calculated to make the preventative variables, as follows:

Household perception = mean (perception1, perception2, perception3)

Environmental mention = mean (Environmental_mention1, Environmental_mention2, Environmental_mention3)

Household innovativeness = mean (Innovativeness1, Innovativesness2, Innovativeness3) 


\section{Government motivation $=$ mean (Government_motivation1, Government_motivation2, Government_motivation)}

Household attitude = mean (Household-attitude1, Household-attitude2, Household - attitude3)

\subsection{Multicollinearity Diagnostics}

Results of the study would not be correct and meaningful if there is multicollinearity among the dependent variables. Therefore, multicollinearity must be diagnosed before regression models are run.

In this situation, all the independent variables including those from $\mathrm{H} 1$ to $\mathrm{H} 5$ had to be added into the model. The multicollinearity diagnostics are in Table 6.

Table 6. Multicollinearity diagnostics.

\begin{tabular}{ccc}
\hline \multirow{2}{*}{ Model } & \multicolumn{2}{c}{ Collinearity Statistics } \\
\cline { 2 - 3 } & Tolerance & VIF \\
\hline (Constant) & & 1.012 \\
Age & 0.988 & 1.013 \\
Gender & 0.987 & 1.118 \\
Education & 0.894 & 1.039 \\
Rooftop_material & 0.962 & 1.09 \\
Level_electricity_consumed & 0.918 & 1.075 \\
Income_per_family_member & 0.93 & 1.183 \\
Household_perception & 0.845 & 1.176 \\
Environmental_mention & 0.85 & 1.137 \\
Household_innovativeness & 0.879 & 1.095 \\
Government_motivation & 0.913 & \\
\hline
\end{tabular}

Dependent Variable: Household_attitude.

As the results in Table 6 show, all the tolerance values are far greater than 0.2 and the VIF values are far less than 5. Thus, there is no multicollinearity in the model. All the variables were evaluated in the analysis.

Regression model for measuring householders' attitude toward rooftop PV installation. All the requirements for the model were tested.

Household - attitude

$$
\begin{aligned}
& =\beta_{0}+\beta_{1} \text { Age } \beta_{2} g e n d e r+\beta_{3} \text { Education } \\
& +\beta_{4} \text { Rooftopmaterial }+\beta_{5} \text { Level_electricity_consum } \\
& +\beta_{6} \text { Incom_per_family_member } \\
& +\beta_{7} \text { Households_perception }+\beta_{8} \text { Environmental_mention } \\
& +\beta_{9} \text { Household_Innovativeness } \\
& +\beta_{10} \text { Government_motivation }+\varepsilon
\end{aligned}
$$

The regression results are shown in Table 7, as follows.

The results from Table 7 show that the Sig values of the independent variables Age, Gender, Rooftop_material, Level_electricity_consumed, Income_per_family_member and Household innovativeness were higher than 0.05. Therefore, the effect of those factors on householders' attitude toward rooftop PV was not significant. It makes no intuitive sense when we concluded that Rooftop_material, Level_electricity_consumed, Income_per_family_member and Household innovativeness are not important. However, at the end of the survey, all the responds said that rooftop PV is a very good alternative energy. If the government has some supports, as shown in Figure 2, they will install the system. They will borrow money from the bank for the initial cost if there is a preferential rate loan for sustainable energy instead of using their own income. People who have a low level of electricity consumption will install a cheaper system than the higher-cost system due to their electricity demand; therefore, Level_electricity_consumed is not important towards their installation decision. Rooftop material was not really an important factor 
because all rooftop PV installations are rigidly framed on the roof to limit the system's direct weight to the roof. In terms of Household innovativeness, currently this research has shown that it is not an important factor. This may create a research gap in this research. In the future, we will test this more strictly by adding more questions on this variable.

Table 7. Parameter Estimates.

\begin{tabular}{cccccc}
\hline \multirow{2}{*}{ Model } & \multicolumn{2}{c}{$\begin{array}{c}\text { Unstandardized } \\
\text { Coefficients }\end{array}$} & $\begin{array}{c}\text { Standardized } \\
\text { Coefficients }\end{array}$ & T & Sig. \\
\cline { 2 - 5 } & $\boldsymbol{B}$ & Std. Error & Beta & & \\
\hline (Constant) & 0.878 & 0.339 & & 2.589 & 0.010 \\
\hline Age & -0.064 & 0.046 & -0.072 & -1.391 & 0.165 \\
\hline Gender & -0.044 & 0.074 & -0.030 & -0.585 & 0.559 \\
\hline Education & 0.117 & 0.053 & 0.120 & 2.208 & 0.028 \\
\hline Level_electricity_consumed & 0.023 & 0.036 & 0.034 & 0.642 & 0.521 \\
\hline Income_per_family_member & 0.025 & 0.027 & 0.051 & 0.953 & 0.341 \\
\hline Household_perception & 0.133 & 0.039 & 0.187 & 3.361 & 0.001 \\
\hline Environmental_mention & 0.107 & 0.038 & 0.158 & 2.837 & 0.005 \\
\hline Household_innovativeness & 0.107 & 0.056 & 0.105 & 1.918 & 0.056 \\
\hline Government_motivation & 0.236 & 0.056 & 0.226 & 4.220 & 0.000 \\
\hline
\end{tabular}

Dependent Variable: Household_attitude.

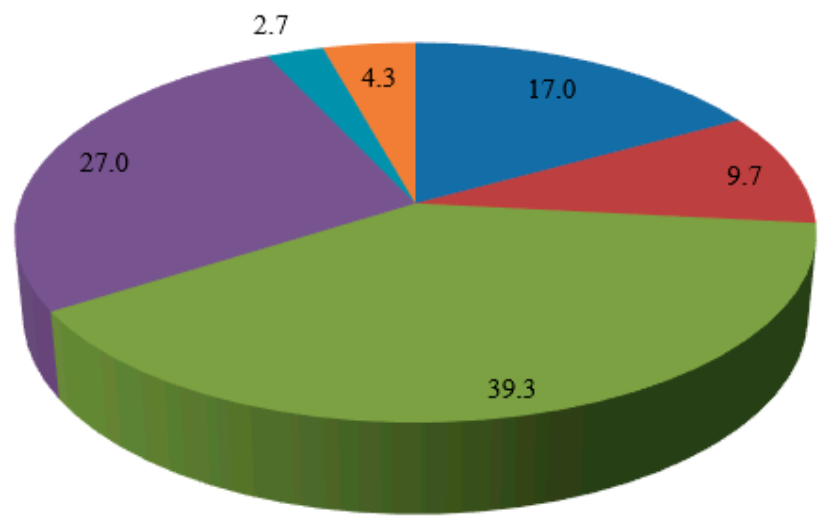

\author{
- Support $10 \%$ innitial cost \\ - Support $20 \%$ innitial cost \\ - Support 30\% innitial cost \\ - Recommend commercial banks to give \\ preferential rate loans \\ - Give 5 million VND bonus for people \\ who install the system \\ "Other
}

Figure 2. Percentage of respondents who recommended government support for rooftop PV development.

The Sig. values of the remaining four variables, including Education, Households_ perception, Environment_mention and Government_motivation, were all less than 0.05; thus, they affected the dependent variable. All four significant variables had the positive coefficient $\beta$, which means that all the effects were in a positive direction. The $\beta$ of Government_motivation (0.236) was the highest, so this factor had the greatest influence on the independent variables. The $\beta$ values of Household_perception, Education and Environment_mention were $0.133,0.117$ and 0.107 , respectively, which means they were also found to be important factors in householders' attitudes toward rooftop PV installation. 
The survey also investigated householders' intentions about rooftop PV and found that $33 \%$ of the households surveyed were willing to pay for the system, while others expressed the view that they may install the system if the government provided some support. Out of 300 respondents, the highest proportion, 39.3\%, (or 118 people) suggested that the government should support $30 \%$ of the initial installation cost, while the remaining respondents wanted support from the government in the form of preferential loans via banks; $10 \%$ or $20 \%$ support for the initial installation cost and VND 5 million in cash. The percentages of people who suggested the above forms of support were $27.0 \%, 17.0 \%$, $9.7 \%$ and $2.7 \%$, respectively. In total, 13 respondents (equivalent to $4.3 \%$ ) want government support in other forms, such as $50 \%$ initial fee support or installation assistance for apartment buildings. Figure 2 illustrates the detail of the percentages of respondents who recommended forms of government support for rooftop PV development.

\section{Discussion}

The study concentrated on testing attitudes toward rooftop PV installation only among householders who live in the Central Highlands of Vietnam, although all the regions of this country are suitable for solar energy exploitation. In addition, only six demographic factors and four factors using a five-point Likert scale were added as the dependent variables of the model. Moreover, the analysis was conducted with only married couples and their families.

Based on the study results, government motivation, household perception, education and environment mentions were the four significant factors that affect household attitudes toward rooftop PV installation. Through the results, it is possible to propose some policy implementations as follows:

- The Vietnamese government has an important role in the development of renewable energy. Therefore, they should conduct a survey to decide the best form of support to provide that fits people's needs when installing rooftop PV systems.

- In addition, education also has an important effect on making people aware of alternative power, and environmental mentions would help people enhance their awareness of environmental protection through using alternative sources of electricity, such as rooftop solar. Policymakers should organize seminars through village meetings to educate people about the meaning of rooftop PV in sustainable energy development, as well as provide incentives for system installation.

- In fact, Vietnam has been successful in implementing gender equality since 2015 and the gap between the two sexes in all main areas of life, including economics, culture, and society, has been significantly narrowed [46]. Erwin (2016) found that the entrepreneurial spirit and gender of both men and women in Vietnam are similar [47]. The results of this study indicate that there is no difference between genders in their attitude towards rooftop PV installations; thus, policymakers can design awarenessraising training equally for both genders, regardless of whether attendees are male or female.

There is a research gap that household innovativeness is not an important factor of households' attitudes in Vietnam. In future study, we will pay more attention to this factor. In addition, the government was considered as the key factor for the development of sustainable energy. In the future, we will research which kinds of motivation that the government needs to give to the people are the most important in the research area.

\section{Conclusions}

Rooftop PV is a source of sustainable energy that alters conventional fossil fuel. People in the Central Highlands of Vietnam can use free electricity 4 to 11 years after the installation of Rooftop PV, depending on their level of electricity consumption. The higher the level of electricity consumed, the shorter the payback period after they install rooftop PV for their electricity consumption [15]. However, the number of households that installed rooftop 
PV in the research area was small. Research on household attitudes towards rooftop PV is crucial for the development of that energy resource.

The results indicate that there was no difference between male and female attitudes towards rooftop PV installation. Government motivation was the most important factor that affected the dependent variable. This was followed by other factors, including household perception, education and environment, which are also necessary for sustainable energy development.

Author Contributions: Conceptualization K.T., T.T.L. and S.J.; methodology, K.T. and T.T.L.; software, K.T.; validation, K.T., T.T.L. and S.J.; formal analysis, T.T.L.; investigation, T.T.L.; resources, K.T. and T.T.L.; data curation, T.T.L.; writing—original draft preparation, T.T.L.; writing-review and editing, K.T., T.T.L. and S.J.; visualization, T.T.L.; supervision, K.T. and S.J.; project administration, S.J.; funding acquisition, K.T. All authors have read and agreed to the published version of the manuscript.

Funding: This research received no external funding.

Institutional Review Board Statement: Not applicable.

Informed Consent Statement: Not applicable.

Data Availability Statement: Not applicable.

Acknowledgments: The authors would like to acknowledge and appreciate the Research and Development Office (RDO) at Prince of Songkla University through to the Grant Num-ENV6402012N-0.

Conflicts of Interest: The authors declare that there is no conflict of interest.

\section{References}

1. Lai, C.S.; McCulloch, M.D. Levelized cost of electricity for solar photovoltaic and electrical energy storage. Appl. Energy 2017, 190, 191-203. [CrossRef]

2. Tongsopit, S.; Junlakarn, S.; Wibulpolprasert, W.; Chaianong, A.; Kokchang, P.; Hoang, N.V. The economics of solar PV selfconsumption in Thailand. Renew. Energy 2019, 138, 395-408. [CrossRef]

3. Lan, T.T.; Jirakiatikul, S.; Techato, K.; Niem, L.D. Opportunities for the development of rooftop solar electricity in Vietnam. J. Crit. Rev. 2020, 7, 1874-1883. [CrossRef]

4. Gupta, R.; Soini, M.C.; Patel, M.K.; Parra, D. Levelized cost of solar photovoltaics and wind supported by storage technologies to supply firm electricity. J. Energy Storage 2020, 27, 101027. [CrossRef]

5. Kaya, A.; Evren Tok, M.; Koc, M. A levelized cost analysis for solar-energy-powered sea water desalination in the Emirate of Abu Dhabi. Sustainability 2019, 11, 1691. [CrossRef]

6. Polo, J.; Bernardos, A.; Navarro, A.A.; Fernandez-Peruchena, C.M.; Ramírez, L.; Guisado, M.V.; Martínez, S. Solar resources and power potential mapping in Vietnam using satellite-derived and GIS-based information. Energy Convers. Manag. 2015, 98, 348-358. [CrossRef]

7. EVN. Vietnam Electricity Annual Report 2018. Available online: https://www.evn.com.vn/userfile/User/tcdl/files/2019/8 /EVNAnnualReport2018(1).pdf (accessed on 10 August 2018).

8. Stickler, C.M.; Coe, M.T.; Costa, M.H.; Nepstad, D.C.; McGrath, D.G.; Dias, L.C.P.; Rodrigues, H.O.; Soares-Filho, B.S. Dependence of hydropower energy generation on forests in the Amazon Basin at local and regional scales. Proc. Natl. Acad. Sci. USA 2013, 110, 9601-9606. [CrossRef]

9. Bui, T.M.H.; Schreinemachers, P.; Berger, T. Hydropower development in Vietnam: Involuntary resettlement and factors enabling rehabilitation. Land Use Policy 2013, 31, 536-544. [CrossRef]

10. Baulch, B.; Duong Do, T.; Le, T.H. Constraints to the uptake of solar home systems in Ho Chi Minh City and some proposals for improvement. Renew. Energy 2018, 118, 245-256. [CrossRef]

11. Hoang, T.D.; Nguyen, A.T.; Nguyen, T.T. Vietnam power system-Overview and challenges. In Proceedings of the 2011 EPU-CRIS International Conference on Science and Technology, Hanoi, Vietnam, 16 November 2011; pp. 1-5, ISBN 978-146-73-0355-2.

12. Eurocham. Whitebook-Trade E Investment Issues and Recommendations, 10th ed.; European Chamber of Commerce in Vietnam: Hanoi, Vietnam, 2018; ISBN 978-604-64-9789-9.

13. Cohen, D.D.; Crawford, J.; Stelcer, E.; Bac, V.T. Long range transport of fine particle windblown soils and coal-fired power station emissions into Hanoi between 2001 to 2008. Atmos. Environ. 2010, 44, 3761-3769. [CrossRef]

14. The Time to Remove the Obstacles to Solar Power Is more Common in Vietnam. Available online: https://vietnambiz.vn/gio-gcho-dien-mat-troi-101440.html (accessed on 28 September 2018).

15. Lan, T.T.; Jirakiattikul, S.; Le, N.D.; Ali, D.; Techato, K. The Effect of Retail Electricity Price Levels on the Financial Indicators of Smart-Grid Rooftop Solar Power Systems: A Case Study in the Central Highlands of Vietnam. Sustainability 2020, 12, 9209. [CrossRef] 
16. Lan, T.T.; Techato, K.; Sopin, J. The Challenge of Feed-In-Tariff (FIT) Policies Applied to the Development of Electricity from Sustainable Resources-Lessons for Vietnam. Int. Energy J. 2019, 19, 199-212.

17. GSO. Population and Housing Census at 0 Hour April 1st 2019; Statistic Publishing: Ha Noi, Vietnam, 2019.

18. EVN. More than 27,600 Rooftop Solar PV Projects Have Been Installed across the Country. Available online: https:/ /www.evn.com. $\mathrm{vn} / \mathrm{d} 6 /$ news/Hon-27600-cong-trinh-dien-mat-troi-mai-nha-da-duoc-lap-dat-tren-ca-nuoc-141-191-25537.aspx (accessed on 20 June 2020).

19. Galan Ladero, M.M.; Galera Casquet, C.; Singh, J. Understanding factors influencing sconsumer attitudes toward cause-related marketing. Int. J. Nonprofit Volunt. Sect. Mark. 2015, 20, 52-70. [CrossRef]

20. Wilkie, W.L.; Pessemier, E.A. Issues in Marketing's Use of Multi-Attribute Attitude Models. J. Mark. Res. 1973, 10, 428. [CrossRef]

21. Asiegbu, F.B.; Iruka, C. Consumer Attitude: Some Reflections on Its Concept, Trilogy, Relationship with Consumer Behavior, and Marketing Implications. Eur. J. Bus. Manag. 2012, 4, 38-50.

22. Hawkins, D.I.; David, L.; Mothersbaugh, R.J.B. Consumer Behavior: Building Marketing Strategy. Business \& Economics: 2007. Available online: https://www.researchgate.net/publication/331588241_Consumer_Bahavior_Building_Marketing_Strategy (accessed on 20 June 2020).

23. Solomon, M.R. Consumer Behavior: Buying, Having, and Being, 12th ed.; Pearson: Harlow, UK, 2018.

24. Sun, P.-C.; Wang, H.-M.; Huang, H.-L.; Ho, C.-W. Consumer attitude and purchase intention toward rooftop photovoltaic installation: The roles of personal trait, psychological benefit, and government incentives. Energy Environ. 2018, 31, 1-18. [CrossRef]

25. Abreu, J.; Wingartz, N.; Hardy, N. New trends in solar: A comparative study assessing the attitudes towards the adoption of rooftop PV. Energy Policy 2019, 128, 347-363. [CrossRef]

26. Tsaur, R.C.; Lin, Y.H. Exploring the consumer attitude of building-attached photovoltaic equipment using revised technology acceptance model. Sustainability 2018, 10, 4177. [CrossRef]

27. Chowdhury, I.; Johnson, H.C.; Mannava, A.; Elizaveta, P. Gender Gap in Earnings in Vietnam: Why Do Vietnamese Women Work in Lower Paid Occupations? J. Southeast Asian Econ. 2019, 36, 400-423. [CrossRef]

28. The Vietnamese Government Daklak Province Information. Available online: https://daklak.gov.vn/du-khach (accessed on 15 March 2020).

29. Statistic office of Daklak. Yearbook Statistics of Daklak Province; Statistic Publishing: Hanoi, Vietnam, 2019.

30. Ostrom, T.M. The relationship between the affective, behavioral, and cognitive components of attitude. J. Exp. Soc. Psychol. 1969, 5, 12-30. [CrossRef]

31. Chisnall, P.M. Marketing: A Behavioral Analysis; McGraw-Hill Book Company (UK) Limited: London, UK, 1975.

32. Johnson, M.; Zinkhan, G.M. Emotional Responses to a Professional Service Encounter. J. Serv. Mark. 1991, 5, 5-16. [CrossRef]

33. Kalwani, M.U.; Silk, A.J. On the Reliability and Predictive Validity of Purchase Intention Measures. Mark. Sci. 1982, 1, 243-286. [CrossRef]

34. Anthony, R.; Pratkanis, S.J.; Breckler, A.G.G. Attitude Structure and Function. Available online: https://www.taylorfrancis.com/ books/attitude-structure-function-anthony-pratkanis-steven-breckler-anthony-greenwald/10.4324/9781315801780 (accessed on 20 June 2020).

35. Saul McLeod Attitudes and Behavior I Simply Psychology. Available online: https://www.simplypsychology.org/attitudes.html (accessed on 21 September 2018).

36. Kotler, P.; Keller, K.L. Marketing Management. Available online: https://www.baaa.dk/programmes/ap-degree/marketingmanagement (accessed on 21 September 2018).

37. Smith, J.R.; Terry, D.J.; Manstead, A.S.; Louis, W.R.; Kotterman, D.; Wolfs, J. The Attitude-Behavior Relationship in Consumer Conduct: The Role of Norms, Past Behavior, and Self-Identity. J. Soc. Psychol. 2008, 148, 311-334. [CrossRef] [PubMed]

38. Sahney, S. Consumer Behavior: Module-6. Available online: https://nptel.ac.in/courses/110105029/pdfsahany/Module.6-27.pdf (accessed on 21 September 2018).

39. Esmailzadeh, M.; Noori, S.; Aliahmadi, A.; Nouralizadeh, H.; Bogers, M. A functional analysis of technological innovation systems in developing countries: An evaluation of Iran's photovoltaic innovation system. Sustainability 2020, 12, 2049. [CrossRef]

40. Rogers, E.M. Diffusion of Innovations, 4th ed.; Simon and Schuster: New York, NY, USA, 2010.

41. Field, A.P. Discovering Statistics Using SPSS: And Sex and Drugs and Rock " $n$ " Roll". Available online: https:/ / books.google.com. hk/books/about/Discovering_Statistics_Using_SPSS.html?id=IY61Ddqnm6IC\&redir_esc=y (accessed on 21 September 2018).

42. Nunnally, J.C. Psychometric Theory, 2nd ed.; McGraw-Hill: New York, NY, USA, 1978; ISBN 0070474656.

43. Menard, S. Applied Logistic Regression Analysis: Sage University Series on Quantitative Applications in the Social Sciences, 2nd ed.; Sam Houston State University: Huntsville, TX, USA; University of Colorado: Denver, CO, USA, 2001.

44. Hair, J.F., Jr.; Black, W.C.; Babin, B.J.; Anderson, R.E. Multivariate Data Analysis, 3rd ed.; Macmillan: New York, NY, USA, 1995.

45. Kennedy, P. A Guide to Econometrics, 6th ed.; Wiley-Blackwell: Oxford, UK, 2008; ISBN 978-1-405-18257-7.

46. ISDS. Social Determinants of Gender Inequality in VIETNAM: Findings of a Research Study between 2012-2015; Institute for Social Development Studies: Hanoi, Vietnam, 2015; pp. 1-161.

47. Bulte, E.; Lensink, R.; Vu, N. Gender training and female empowerment: Experimental evidence from Vietnam. Econ. Lett. 2016, 145, 117-119. [CrossRef] 